\title{
Postoperatif Ağrı Kontrolünde Preemptif ve Postoperatif Tek Doz Tenoksikam Uygulamasının Etkinliğinin Karşılaştırılması
}

\author{
Ayşe Neslihan BALKAYA ${ }^{1}$, Fatma Nur KAYA ${ }^{2}$, Filiz ATA ${ }^{1}$, Ümran KARACA ${ }^{1}$ \\ 1 Sağlık Bilimleri Üniversitesi Bursa Yüksek İhtisas Eğitim ve Araştırma Hastanesi, Anesteziyoloji ve Reani- \\ masyon Kliniği, Bursa. \\ 2 Bursa Uludağ Üniversitesi Tıp Fakültesi, Anesteziyoloji ve Reanimasyon Anabilim Dalı, Bursa.
}

\section{ÖZET}

Çalışmamızda mastektomi uygulanan hastalarda preemptif ve postoperatif tenoksikam kullanımının postoperatif ağrı üzerine etkilerinin karşılaş̦tırılması amaçlandı. Haziran 2009-Eylül 2010 tarihleri arasında mastektomi uygulanan 75 hasta çalışmaya dahil edildi. Preemptif tenoksikam grubundaki (Grup CÖ-T, n=25) hastalara cerrahi başlangıcından $30 \mathrm{dk}$ önce tenoksikam $20 \mathrm{mg}$ iv (2 ml), cerrahi bitiminde serum fizyolojik (SF) $2 \mathrm{ml}$ iv verildi. Cerrahi sonrası tenoksikam uygulanan gruptaki (Grup CB-T, n=25) hastalara ise cerrahi başlangıcından $30 \mathrm{dk}$ önce SF, cerrahi bitiminde tenoksikam uygulandı. Kontrol grubundaki (Grup Kontrol, n=25) hastalara ise cerrahi başlangıcından $30 \mathrm{dk}$ önce ve cerrahi bitiminde SF uygulandı. Postoperatif hasta kontrollü analjezi başlandı. Postoperatif Görsel Analog Skala (VAS) değerleri, bulantıkusma şiddeti ve morfin kullanım miktarları ile postoperatif ilk analjezik gereksinim ve mobilizasyon zamanları, hastanede kalıș süreleri, 24 saatlik morfin tüketimleri, postoperatif komplikasyonlar, hasta ve hemşire memnuniyetleri kaydedildi. Postoperatif derlenme ünitesinde yapılan ilk değerlendirme (0. saat) VAS değeri Grup CÖ-T ve Grup CB-T'de benzer, Grup-Kontrol'de yüksek bulundu. ( $<<0,05)$. Diğer saatlerde VAS değerlerinde gruplar arasında fark yoktu. Hastaların ilk analjezik gereksinim zamanı Grup CÖ-T'de en uzun, Grup Kontrol'de en kısaydı $(\mathrm{p}<0,001)$. Postoperatif saatlik morfin tüketimleri ve 24 saatlik toplam morfin tüketimi Grup CÖ-T'de en düşüktü. Postoperatif bulantı-kusma en fazla Grup Kontrolde gözlendi. Hasta memnuniyeti tenoksikam kullanılan gruplarda yüksek bulunurken kontrol grubunda düşüktü $(\mathrm{p}<0,05)$. Postoperatif ilk mobilizasyon zamanları, hastanede kalış süreleri ile hemşirelerin memnuniyet düzeyleri gruplar arasında benzer bulundu. Preemptif tenoksikam uygulamasının ilk analjezik gereksinim zamanını uzatması, postoperatif morfin tüketimini azaltması sebebiyle mastektomi uygulanan hastalarda postoperatif ağrı kontrolünde etkin olduğu kanısındayız.

Anahtar Kelimeler: Tenoksikam. Preemptif. Postoperatif ağrı.

Comparison of the Effectiveness of Preemptive and Postoperative Single Dose Tenoxicam in Postoperative Pain Control

\begin{abstract}
In our study, we aimed to compare the effects of preemptive and postoperative tenoxicam use on postoperative pain in patients undergoing mastectomy. 75 patients with mastectomy between June 2009-September 2010 were included to the study. In preemptive tenoxicam group

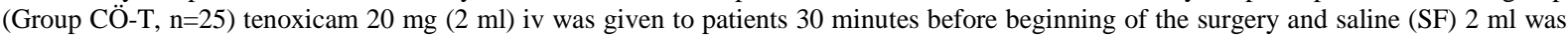
given iv at the end of the surgery. In postoperative tenoxicam group (Group CB-T, n=25) patients were administered SF 2 ml iv 30 minutes before beginning of surgery and tenoxicam $20 \mathrm{mg}$ at the end of the surgery. In the control group (Group Control, $\mathrm{n}=25$ ) SF $2 \mathrm{ml}$ iv was applied to patients 30 minutes before beginning of the surgery and at the end of the surgery. Postoperative patient-controlled analgesia was started. Postoperative Visual Analogue Scale (VAS) values, severity of nausea-vomiting and the amount of morphine usage, postoperative first analgesic requirement and mobilization times, hospital stays, 24-hour morphine consumption, postoperative complications, patient and nurse satisfaction were recorded. VAS values at 0th hour were found similar in Group CÖ-T and Group CB-T, but high in Group Control (p $<0.05)$. There was no difference between the groups in VAS values at the other hours. The first analgesic requirement time of the patients was longest in Group CÖ-T and shortest in Group Control ( $\mathrm{p}<0.001$ ). Postoperative hourly and 24-hour morphine consumption were lowest in Group CÖ-T. Postoperative nausea and vomiting were observed mostly in Group Control. Patient satisfaction was higher in the tenoxicam groups than in Group Control $(\mathrm{p}<0.05)$. Postoperative first mobilization times, hospital stays and nurses satisfaction level were similar between the groups. We are of the opinion that preemptive tenoxicam usage is effective in postoperative pain control in patients undergoing mastectomy due to prolonging the initial analgesic requirement time and reducing the consumption of postoperative morphine.
\end{abstract}

Key Words: Tenoxicam. Preemptive. Postoperative pain.

Gelis Tarihi: 02 Subat 2021

Kabul Tarihi: 14.Nisan.2021

Dr. Ayşe Neslihan BALKAYA

Sağlık Bilimleri Üniversitesi

Bursa Yüksek İhtisas Eğitim ve Araştırma Hastanesi,

Anesteziyoloji ve Reanimasyon Kliniği, Bursa.

Tel: 05448715343

E-posta: aynesbalkaya@gmail.com
Yazarların ORCID ID Bilgisi:

Ayşe Neslihan BALKAYA: 0000-0001-8031-6264

Fatma Nur KAYA: 0000-0002-2655-9844

Filiz ATA: 0000-0003-2472-1681

Ümran KARACA: 0000-0001-5922-2300 
Meme kanseri, kadınlarda en sık görülen kanser tiplerindendir ve cerrahi tedavi en geçerli tedavi yöntemi$\operatorname{dir}^{1}$. Postoperatif ağrı, mastektomili hastalarda cerrahi sonrasında s1k görülen bir problem olduğundan akut ağrı tedavisi çalışmaların ortak hedefi olmaya devam etmektedir. Meme cerrahisi sonrasında uygulanacak etkin ağrı kontrolü, kronik ağrı gelişiminde azalma, hasta memnuniyetinde artma, postoperatif morbidite oranlarında azalma, hızlı iyileşme ve rehabilitasyona olanak sağlamaktadır ${ }^{2}$. Postoperatif ağrı kontrolünde s1klıkla tercih edilen güncel yöntem multimodal analjezidir. Multimodal analjezi, değişik etki mekanizmasına sahip iki ya da daha fazla sayıda analjezik ilaç veya yöntemin birlikte kullanılmasıdır. Multimodal analjezi uygulanan hastalarda postoperatif opioid tüketiminde azalma saptanmaktadır ${ }^{3-5}$. Multimodal analjezinin bir parçası olarak kabul edilen preemptif analjezi, preoperatif dönemde ağrılı uyarı verilmeden periferik ve santral hassaslaşmaya engel olarak, uyaran sonrası ağrı oluşumunu engellemeyi ya da şiddetini azaltmayı amaçlayan bir tekniktir. Bu amaçla rejyonal anestezi, opioidler, nonsteroid antiinflamatuar (NSAIII) ilaçlar, diğer analjezikler ve psikolojik yöntemler kullanılmaktadır ${ }^{6,7}$. Multimodal analjezi rejimlerinde NSAIII'ler preoperatif olarak başlanır ve postoperatif dönemde devam edilir ${ }^{3,8}$.

Tenoksikam, nonselektif NSAIII'lerin oksikam grubundan, uzun etkili, antiinflamatuvar, analjezik ve antipiretik etkinliği olan bir ilaçtır. Tenoksikam intravenöz (iv) kullanılabilmesi, uzun eliminasyon yarı ömrüne sahip olması ve günde tek dozla etkin analjezi sağlaması sebebiyle postoperatif ağrı kontrolü çalışmalarında sıklıkla kullanılmaktadır ${ }^{9,10}$.

Bu çalışmada amacımız; mastektomi uygulanan hastalarda preemptif ve postoperatif tenoksikam $20 \mathrm{mg}$ iv uygulamasının postoperatif dönemde ağr1 ve bulant1kusma şiddetleri ve morfin tüketimi, ilk analjezik gereksinim ve mobilizasyon zamanları, postoperatif komplikasyonlar, hastanede kalış süresi, hasta ve hemşire memnuniyeti üzerine etkilerinin karşılaştırılmasıdir.

\section{Gereç ve Yöntem}

Çalışmamız Uludağ Üniversitesi Tıp Fakültesi Tıbbi Araştırmalar Etik Kurul 26/05/2009 tarihli ve 20099/60 karar numaralı onayı ve hastalardan yazılı aydınlatılmış onamları alınarak gerçekleştirildi. Haziran 2009-Eylül 2010 tarihleri arasında mastektomi uygulanan Amerikan Anestezistler Cemiyeti (The American Society of Anesthesiology; ASA) I ve II grubu, 18-70 yaş arası 75 kadın hasta çalışmaya dahil edildi. Çalışma prospektif, randomize ve çift kör olarak planland. NSAIII'lere karşı alerji öyküsü, peptik ülser, özofagus varisi, pıhtılaşma bozuklukları, karaciğer ve/veya böbrek yetmezliği, reaktif havayolu hastalığı olanlar, sitotoksik ilaç ve/veya potasyum tutucu diüretik ilaç kullananlar, gebelik varlığı ya da şüphesi bulunan hastalar çalışma dışı bırakıldı.

Tüm hastalara operasyon öncesi postoperatif ağr1 şiddetinin değerlendirilmesi için Görsel Analog Skala (VAS) (0: Ağrı yok, 10: Tahmin edilebilecek en şiddetli ağrı) ve postoperatif ağrı kontrolünde kullanılacak Hasta Kontrollü Analjezi (HKA) yöntemi hakkında bilgi verildi. Premedikasyon uygulanmayan ve 8 saatlik açlığı takiben ameliyathaneye alınan hastalara elektrokardiyografi (EKG), periferik oksijen saturasyonu $\left(\mathrm{SpO}_{2}\right)$, non invaziv kan basıncı monitorizasyonu uygulandı ve iv damaryolu açılarak \%0,9 NaCI, 10 $\mathrm{mg} / \mathrm{kg} / \mathrm{sa}$ hızında infüzyona başlandı. Hastaların demografik özellikleri ve ASA sınıflaması kaydedildi. Çalışmaya dahil edilen hastalar kapalı zarf tekniği ile 3 gruba ayrıldı. Preemptif tenoksikam grubundaki (Grup CÖ-T, n=25) hastalara cerrahi başlangıcından 30 dk önce tenoksikam (Tilcotil®), Deva İlaç Sanayi, İstanbul, Türkiye) $2 \mathrm{ml}$ iv (20 mg), cerrahi bitiminde serum fizyolojik (SF) $2 \mathrm{ml}$ iv verildi. Cerrahi sonrası tenoksikam uygulanan gruptaki (Grup CB-T, $n=25$ ) hastalara ise cerrahi başlangıcından $30 \mathrm{dk}$ önce SF 2 $\mathrm{ml}$ iv, cerrahi bitiminde tenoksikam $2 \mathrm{ml}$ iv (20 mg) uyguland1. Kontrol grubundaki (Grup Kontrol, n=25) hastalara ise cerrahi başlangıcından $30 \mathrm{dk}$ önce ve cerrahi bitiminde SF $2 \mathrm{ml}$ iv olarak uyguland. Anestezi indüksiyonu kirpik refleksi kayboluncaya kadar propofol (Propofol 1\%®, Fresenius Kabi, Avusturya), fentanil (Fentanyl Citrate ${ }^{\circledR}$, Abbot, USA) $2 \mu \mathrm{g} / \mathrm{kg}$ ve rokuronyum (Esmeron ${ }^{\circledR}$, Merck Sharp Dohme İlaç Sanayi, Hollanda) $0,6 \mathrm{mg} / \mathrm{kg}$ ile sağlandı. Anestezi idamesinde 2 litre taze gaz akımı, \%1,5-2 minimum alveolar konsantrasyon sevofluran uyguland1, kas gevşetici ihtiyacı rokuronyum $0,1 \mathrm{mg} / \mathrm{kg}$ tekrarlayan dozları ile sağland. Her üç grupta cerrahi öncesi dönemde çalışma ilacı verilmeden önce (D1-kontrol) ve verildikten sonra (D2), cerrahi bitiminde çalışma ilacı uygulanmadan önce (D3) ve uyguladıktan sonra (D4) kalp hızı (KH), sistolik (SAB) ve diyastolik (DAB) arter basınçları, $\mathrm{SpO}_{2}$, soluk sonu $\mathrm{CO}_{2}\left(\mathrm{EtCO}_{2}\right)$ değerleri kaydedildi. Parametreler anestezi indüksiyonundan önce, indüksiyon esnasında, indüksiyondan $1 \mathrm{dk}$ sonra, laringoskopi sırasında, entübasyon sonrası 1 , $10,20,30,40,50$ ve 60 . dk'larda, ekstübasyonda ve ekstübasyondan $1 \mathrm{dk}$ sonra kaydedildi. Hipertansiyon (kontrol değerin \%20 üstü veya $\mathrm{SAB}>150 \mathrm{~mm} \mathrm{Hg}$ olmas1), hipotansiyon (kontrol değerin \%20 altı veya $\mathrm{SAB}<110 \mathrm{atım} / \mathrm{dk}$ olması), taşikardi (kontrol değerin \%20 üstü veya $\mathrm{KH}>110 \mathrm{atım} / \mathrm{dk}$ olması), bradikardi (kontrol değerin \%20 altı veya veya $\mathrm{KH}<40$ atım/dk olması) kaydedildi. Bronkospazm, diş ve hava yolları hasarı, alerjik reaksiyon gibi intraoperatif gelişebilecek komplikasyonlar kayıt altına alındı. İntraoperatif ağrı varlığı, indüksiyondan sonraki kontrol değerlere göre arteryel kan basıncında ve kalp hızında \%20'den fazla artışa göre belirlenerek, ağrı varlığında fentanil iv $1 \mu \mathrm{g} / \mathrm{kg}$ uygulandı. Cerrahi girişim 


\section{Preemptif ve Postoperatif Tenoksikam Kullanımı}

sonlandıktan sonra dekürarizasyon amacıyla atropin iv $0,02 \mathrm{mg} / \mathrm{kg}$ ve neostigmin iv $0,05 \mathrm{mg} / \mathrm{kg}$ uyguland . Ekstübasyon sonrası spontan solunumu olan ve sözlü uyarılara yanıt alınan hastalar derlenme ünitesine alındı. Cerrahi süresince kullanılan fentanil miktarları, cerrahi ve anestezi süreleri kaydedildi.

Bütün hastalara morfin ile iv HKA cihazı $1 \mathrm{mg} / \mathrm{ml}$ konsantrasyonda morfin olacak $2 \mathrm{mg}$ bolus doz, $15 \mathrm{dk}$ kilit süresi ve $24 \mathrm{mg} 4$ saatlik limit olacak şekilde programlanarak, postoperatif HKA tedavisi başlandı, yükleme dozu kullanılmadı. Derlenme ünitesinde hastalar postoperatif ağrı (VAS skorlaması) ve bulantı-kusma açısından (yok, hafif, orta, şiddetli) değerlendirildi. Postoperatif derlenme ünitesine ulaştığında yapılan ilk değerlendirme postoperatif sıfirıncı saat olarak kabul edildi. Postoperatif dönemde, Modifiye Aldrete Skoru 9 ve üstü olduğunda hastalar derlenme ünitesinden kliniğine gönderildi. Hastaların postoperatif dönemde 0, 2, 4, 8, 12 ve 24. saatlerde VAS skorlar1, bulantı-kusma şiddeti ve kullanılan morfin miktarları kaydedildi. Postoperatif dönemde hastalara ek analjezik ajan kullanılmadı. Orta ve şiddetli bulantıkusma şikayeti olan hastalara metoklopramid $10 \mathrm{mg}$ iv uygulanması planlandı. İlk mobilizasyon zamanları, 24 saatlik toplam kullanılan morfin miktarları, postoperatif ilk 24 saatte gelişen komplikasyonlar (taşikardi, hipertansiyon, bradikardi, hipotansiyon, üşüme titreme, baş ağrısı, boğaz ağrısı) ve taburculuk süreleri ile postoperatif ilk 24 saatteki hasta ve hemşire memnuniyeti (memnun, kararsız, memnun değil) verileri kaydedildi.

\section{Biyoistatistiksel Analiz}

Çalışmamızın istatistiksel analizi SPSS 21.0 istatistik paket programında yapıldı. Verilerin normal dağılım gösterip göstermediği “Kolmogorov Smirnov” testi ile incelendi. Gruplar arası karşılaştırmada normal dağ1$11 \mathrm{~m}$ gösteren veriler için "Varyans Analizi”, normal dağılım göstermeyenler için de "Kruskal Wallis” testi kullanıldı. Gruplar arasında normal dağılım gösteren veri için "Bağımsız örneklemler t" testi, normal dağ1lım göstermeyen veri için "Wilcoxon" testi kullanıldı. Gruplar arası fark bulunduğunda "Kruskal Wallis" testinin posthoc testi olarak "Mann-Whitney U” testi kullanıldı. Kategorik verilerin incelenmesinde "Pearson Ki-kare” testi kullanıldı. Çalışmada p değeri anlamlılık düzeyi $\mathrm{p}<0.05$ olarak belirlendi.

\section{Bulgular}

Gruplar arasında demografik veriler (yaş, boy, kilo), ASA sınıflaması, cerrahi ve anestezi süreleri arasında anlamlı fark bulunmadı (Tablo I). Gruplar arası intraoperatif fentanil kullanımı benzerdi $(p>0,05)$
Tablo I. Demografik Veriler, ASA Sinıflaması, Cerrahi ve Anestezi Süreleri

\begin{tabular}{|l|r|r|r|r|}
\hline & \multicolumn{1}{|c|}{$\begin{array}{c}\text { Grup CÖ-T } \\
(n=25)\end{array}$} & \multicolumn{1}{c|}{$\begin{array}{c}\text { Grup CB-T } \\
(n=25)\end{array}$} & $\begin{array}{c}\text { Grup } \\
\text { Kontrol } \\
(n=25)\end{array}$ & \multicolumn{1}{c|}{$\begin{array}{c}p \\
\text { değeri }\end{array}$} \\
\hline Yaş (yll) & $49,9 \pm 14,2$ & $48,6 \pm 13,3$ & $50,2 \pm 9,9$ & 0,89 \\
\hline Kilo (kg) & $72,8 \pm 10,2$ & $68,7 \pm 11,6$ & $68 \pm 11,4$ & 0,24 \\
\hline Boy (cm) & $159,9 \pm 3,6$ & $159,1 \pm 4,4$ & $158,6 \pm 2,2$ & 0,47 \\
\hline ASA & & & & \\
\hline \multicolumn{1}{|c|}{ I (n,\%) } & $15(\% 60)$ & $14(\% 56)$ & $16(\% 64)$ & 0,93 \\
\hline \multicolumn{1}{|c|}{ II (n,\%) } & $10(\% 40)$ & $11(\% 44)$ & $9(\% 36)$ & 0,90 \\
\hline Cerrahi süresi (dk) & $113,4 \pm 38,5$ & $112,4 \pm 39,3$ & $99,8 \pm 29,8$ & 0,19 \\
\hline Anestezi süresi (dk) & $127,6 \pm 39,2$ & $126,2 \pm 40,1$ & $114,8 \pm 32,2$ & 0,31 \\
\hline
\end{tabular}

ASA: AmericanSociety of Anesthesiologists (Amerikan Anestezistler Cemiyeti)

n: hasta sayısı, \%: yüzdelik değer, ort \pm SS: ortalama \pm standart sapma

Cerrahi başlamadan ve cerrahi bitiminde çalışma ilaçlarının uygulamasında, uygulama öncesi (D1-D3) ve uygulama sonrası (D2-D4) zamanlarda kaydedilen $\mathrm{KH}$, $\mathrm{SAB}, \mathrm{DAB}, \mathrm{SpO}_{2}$ ve $\mathrm{ETCO}_{2}$ değerleri gruplar arasında benzer bulundu.

İntraoperatif dönemdeki tüm ölçüm zamanlarında $\mathrm{KH}$, $\mathrm{SAB}, \mathrm{DAB}, \mathrm{SpO}_{2}$ ve $\mathrm{ETCO}_{2}$ değerleri gruplar arasında benzer bulundu.

İntraoperatif dönemde Grup CÖ-T ve Grup CB-T'dan bir, Grup Kontrol'den iki olmak üzere toplam dört hastada hipotansiyon, Grup CÖ-T ve Grup CB-T'da birer hasta ve Grup Kontrol'de iki hasta olmak üzere toplam dört hastada bradikardi gözlendi. Grup CÖT'da dört, Grup CB-T'da beş ve Grup Kontrol'de üç hasta olmak üzere toplam on iki hastada hipertansiyon gözlendi. Hipertansiyon gelişen hastalarda ek fentanil uygulaması ve inhalasyon ajanının arttırılması ile mevcut tablolarda gerileme gözlendi, ek medikal tedavi uygulanmadı. İntraoperatif dönemde hipotansiyon/hipertansiyon ve bradikardi gelişen hasta sayıları gruplar arasında benzerdi, taşikardi gözlenen hasta olmadı. İntraoperatif komplikasyon gelişimi olmadi.

Postoperatif ağrı değerlendirmesinde, derlenme ünitesinde bakılan 0. saat VAS değeri Grup CÖ-T ve Grup CB-T'da benzer bulunurken kontrol grubunda VAS değeri diğer iki gruba göre yüksek bulundu $(p<0,05)$. Diğer saatlerde VAS değerleri açısından gruplar arasında fark saptanmadı (Şekil 1). 
A.N. Balkaya, ark.

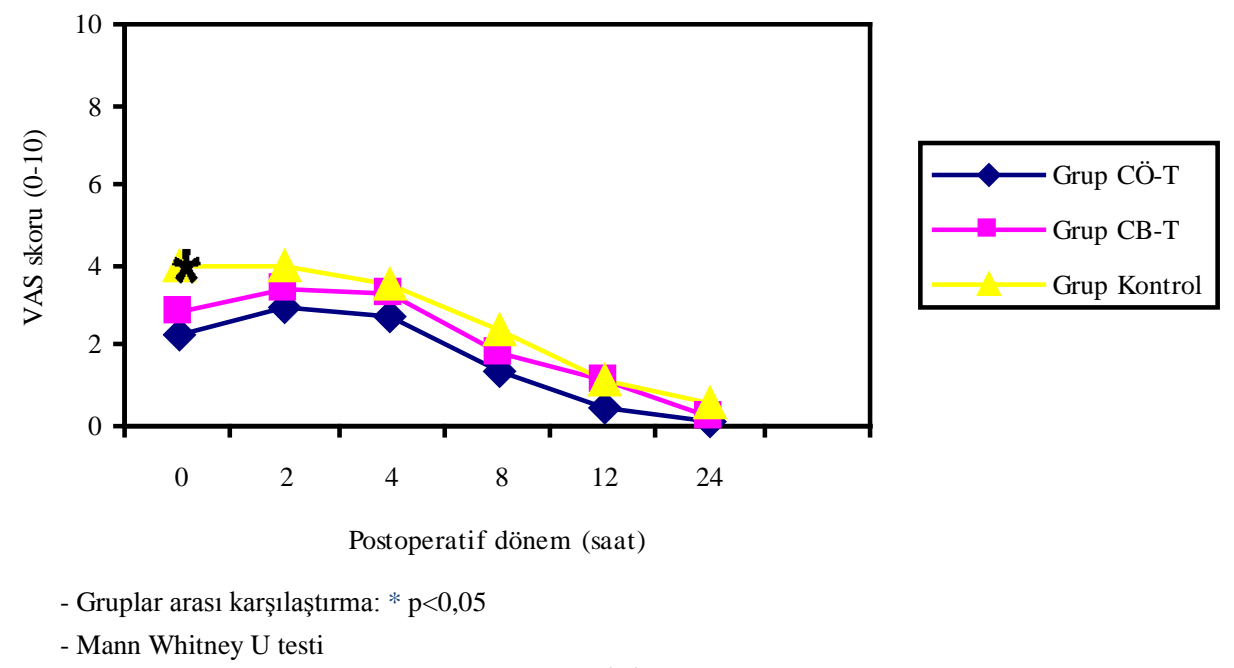

Şekil 1:

Postoperatif ăgrının Görsel Analog Skala (VAS) skoru (0-10) değişimlerinin gruplar arası karşılaştırılması (Ortalama \pm Standart Sapma).

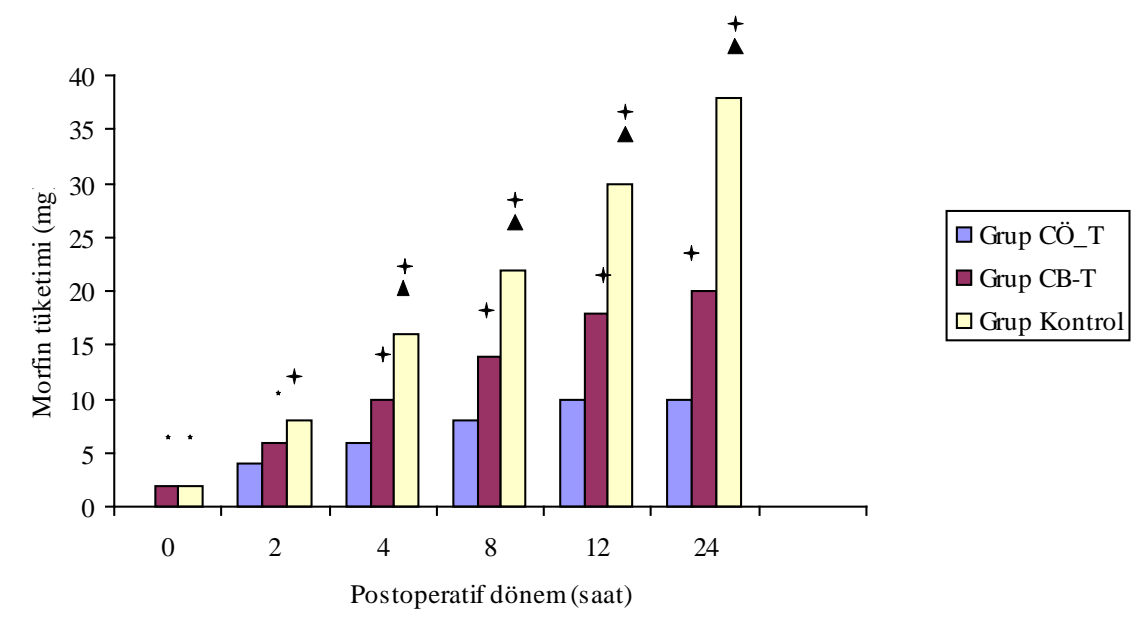

$$
\begin{array}{lc}
\text { - Grup CÖ-T'ın diğer } 2 \text { grup ile karşıllaştırılması: } & * \mathrm{p}<0,05 \\
& +\mathrm{p}<0,001 \\
& \boldsymbol{\Delta} \mathrm{p}<0,05 \\
\text { - Grup Kontrol ile Grup CB-T'ın karşıllaştırılması } & \\
\text { - Mann Whitney U test } &
\end{array}
$$

Şekil 2:

Postoperatif dönemde morfin tüketiminin gruplar arası karşılaştırılması (miligram, Ortalama \pm Standart Sapma).

Hastaların postoperatif HKA ile morfin tüketimleri Grup CÖ-T'da postoperatif 0, 2, 4, 8, 12 ve 24. saatlerde sirasiyla $0 \pm 1,15,4 \pm 2,05,6 \pm 3,49,8 \pm 4,15$, $10 \pm 4,86,10 \pm 4,70 \mathrm{mg}$ şeklinde bulundu. Grup CÖT'da saatlik morfin tüketimleri diğer iki gruba göre daha düşük saptandi. Grup Kontrol'deki hastaların 0 ve 2 . saatteki morfin tüketimleri $2 \pm 1.0$ ve $8 \pm 2,49 \mathrm{mg}$, Grup CB-T'da ise aynı saatlerde $2 \pm 1,01$ ve $6 \pm 2,70 \mathrm{mg}$ şeklinde bulundu Postoperatif 0 ve 2 . saatlerde kontrol grubu ile Grup CB-T'da morfin tüketimleri benzer bulunurken Grup CÖ-T'dan yüksek bulundu. Postoperatif $4,8,12,24$. saatlerde hastaların saatlik morfin tüketimi kontrol grubunda Grup CB-T'dan yüksek bulundu $(\mathrm{p}<0,05)$ (Şekil 2). Hastaların 24 saatlik top- lam morfin tüketimleri Grup CÖ-T’da 11,5£4,7 mg, Grup CB-T'da 21,6 $\pm 5,5$ mg, Grup Kontrol'de $37,5 \pm 10,5 \mathrm{mg}$ olarak bulundu. Hastaların 24 saatlik toplam morfin tüketimi en az Grup CÖ-T'da olduğu, kontrol grubunda morfin kullanımının diğer gruplardan yüksek olduğu saptand $1(\mathrm{p}<0,001)$. Postoperatif dönemde hastaların ilk analjezik gereksinim (ilk HKA kullanma zamanı) zamanları kontrol grubunda postoperatif 2,2 $\pm 0,1$. dk, Grup CB-T'da 13,3 $\pm 11,9$. dk, Grup CÖ-T’da 31,2ะ16,9. dk olarak bulundu, gruplar arasında istatistiksel olarak anlamlı fark bulundu $(\mathrm{p}<0,001)$. Hastaların postoperatif dönemde ilk mobilizasyon zamanları ve hastanede kalış süreleri her üç grupta benzerdi (Tablo II). 
Tablo II. İlk analjezik gereksinim zamanları, 24 saatlik morfin tüketimleri, ilk mobilizasyon zamanları ve hastanede kalış sürelerinin karşılaştırılması

\begin{tabular}{|l|c|c|c|c|}
\hline & $\begin{array}{c}\text { Grup CÖ-T } \\
(n=25)\end{array}$ & $\begin{array}{c}\text { Grup CB-T } \\
(n=25)\end{array}$ & $\begin{array}{c}\text { Grup } \\
\text { Kontrol } \\
(n=25)\end{array}$ & $\begin{array}{c}p \\
\text { değeri }\end{array}$ \\
\hline $\begin{array}{l}\text { IIlk analjezik } \\
\text { gereksinim zamanı(dk) }\end{array}$ & $31,2 \pm 16,9$ & $13,3 \pm 11,9$ & $2,2 \pm 0,1$ & $<0,001^{*}$ \\
\hline $\begin{array}{l}\text { 24 saatlik morfin } \\
\text { tüketimi (mg) }\end{array}$ & $11,5 \pm 4,7$ & $21,6 \pm 5,5$ & $37,5 \pm 10,5$ & $<0,001^{*}$ \\
\hline $\begin{array}{l}\text { IIlk mobilizasyon } \\
\text { zamanı(saat) }\end{array}$ & $4,0 \pm 1,5$ & $3,8 \pm 1,2$ & $4,1 \pm 2,2$ & 0,88 \\
\hline $\begin{array}{l}\text { Hastanede kalış } \\
\text { süresi (saat) }\end{array}$ & $26,2 \pm 3,0$ & $28,0 \pm 4,1$ & $26,8 \pm 4,3$ & 0,26 \\
\hline
\end{tabular}

Mann Whitney U testi

* Gruplar arası karşılaştırmada $\mathrm{p}<0,001$

Ort \pm SS: ortalama \pm standart sapma; dk: dakika

Postoperatif sıfırıncı saatte Grup CÖ-T’da 3 hastada hafif, Grup CB-T'da 2 hastada hafif, 4 hastada orta düzeyde, Grup Kontrol'de 6 hastada hafif, 1 hastada orta, 1 hastada şiddetli düzeyde bulant1-kusma görüldü. Postoperatif ikinci saatte Grup CÖ-T’da 5 hastada hafif, 2 hastada orta, Grup CB-T'da 10 hastada hafif, 5 hastada orta düzeyde, Grup Kontrol'de 12 hastada hafif, 7 hastada orta düzeyde bulant1-kusma görüldü. Postoperatif dördüncü saatte ise Grup CÖ-T’da 3 hastada hafif, Grup CB-T'da 8 hastada hafif düzeyde, Grup Kontrol'de 9 hastada hafif, 3 hastada orta, 2 hastada şiddetli düzeyde bulantı-kusma görüldü. Postoperatif ilk 4 saatte bulant1-kusma en az Grup CÖT'da saptand1 $(\mathrm{p}<0,05)$. İlk 2 saatte Grup CB-T ve Grup Kontrol arasında istatistiksel fark yokken 4. saatte Grup Kontrol'de bulantı-kusma görülen hasta sayısı Grup CB-T'a göre fazla saptandı $(\mathrm{p}<0,05)$. Postoperatif 4. saatten sonra Grup CÖ-T ve CB-T'da bulant1-kusma gözlenmezken kontrol grubunda 8 . saatte hafif-orta düzeyde 8 hastada, 12 . saatte hafiforta düzeyde 2 hastada ve 24 . saatte hafif düzeyde 1 hastada bulant1-kusma görüldü $(\mathrm{p}<0,05)$. Postoperatif ilk 24 saatlik dönemde klinik takiplerinde Grup CÖ-T ve Kontrol'de birer hasta, Grup CB-T'da iki hasta olmak üzere toplam dört hastada baş dönmesi; Grup CÖ-T ve CB-T'da üçer hasta, Grup Kontrol'de bir hasta olmak üzere toplam yedi hastada hipertansiyon gözlendi. Grup CB-T ve Kontrol'de birer hasta olmak üzere toplam iki hastada üşüme titreme; Grup CÖ-T ve CB-T'da birer hasta olmak üzere toplam iki hastada boğaz ağrısı şikayeti gözlendi.

Grup CÖ-T ve Grup CB-T arasında postoperatif hasta memnuniyeti açısından fark saptanmadı. Postoperatif hasta memnuniyet düzeyleri kontrol grubunda diğer 2 gruba göre daha düşük bulundu $(\mathrm{p}<0,05)$. Hasta takibinden sorumlu olan klinik hemşirelerinin postoperatif 24 saatlik memnuniyet düzeyleri gruplar arasında benzer saptand1.

\section{Tartışma ve Sonuç}

Mastektomi uygulanan hastaların postoperatif ağrı kontrolünde preemptif tenoksikam kullanımının postoperatif kullanım ve plasebo ile karşılaştırıldığı çalışmamızda; preemptif tenoksikam uygulamasının postoperatif dönemde ilk analjezik gereksinim zamanını uzattığı ve postoperatif morfin tüketimini azalttığ görüldü. Bununla birlikte hastaların ilk mobilizasyon zamanları ve hastanede kalış süreleri ile klinik takiplerden sorumlu olan hemşirelerin memnuniyet düzeyleri gruplar arasında benzer bulundu. Hasta memnuniyeti tenoksikam uygulanan gruplarda benzer bulunurken plasebo uygulanan grupta daha düşük saptandı.

Yeni cerrahi teknikler ve anestezi yöntemlerine rağmen postoperatif ağrı önemli bir sorun olmaya devam etmektedir. Postoperatif ağrı tedavisinde amaç, hastanın ağrısını azaltmak veya ortadan kaldırmak, organizmada artan sempatoadrenerjik aktiviteye bağlı oluşabilecek komplikasyonları engellemek, mortalite ve morbiditeyi en aza indirmek, hastada erken mobilizasyon sağlayarak hastanede yatış süresini kısaltmak ve tedavi maliyetini düşürmek olmalıdır ${ }^{11}$. Postoperatif ağrı ve bunun yaratacağı anksiyete sistemler üzerinde olumsuz etki yaratmakta ve organizmanin uygulanan cerrahi işleme verdiği stres yanıtını arttırmaktadır, bu sebeple preoperatif dönemden başlayarak gerekli önlemler alınmalıdır. Preemptif analjezinin amac1 sinir sisteminde ağrı hafizası oluşumunu önlemek veya azaltmak, böylece analjezi ihtiyacını azaltmak$\mathrm{t}_{1 \mathrm{r}}^{6,12}$. Preemptif analjezi için parenteral ve oral NSAIII, sublingual ve oral opioidler, parenteral N-Metil-DAspartik Asit (NMDA) reseptör antagonistleri, lokal anestezikler (rejyonal anestezi, yara yeri infiltrasyonu), sistemik alfa-2 agonistleri ve gama amino butirik asit (GABA) analogları sıkça kullanılmaktadır ${ }^{6,7}$. Preemptif analjezide hangi yol ya da ajanın başarılı olduğu hala tartışılmaktadır. Meme cerrahisinde postoperatif ağrının tedavisi için preoperatif lokal anestezik infiltrasyonu, interkostal sinir bloğu, torasik epidural blok ve paravertebral blok gibi çeşitli bölgesel teknikler kullanılmıştır. Bu yaklaşımlarla postoperatif dönemde etkili analjezi sağlanırken hastalarda daha az peroperatif hemodinamik değişiklik görülmektedir ${ }^{13-16}$. Raj ve $\operatorname{ark}^{\prime}{ }^{17}{ }^{17}$ mastektomilerde preemptif pregabalin kullanmışlar, postoperatif VAS skorları ve opioid ihtiyacında düşüş olduğunu, intraoperatif dönemde laringoskopi ve entübasyona bağlı hemodinamik yanıtta azalma gördüklerini bildirmişlerdir. Bharti ve ark'larının $^{18}$ preemptif gabapentin kullandıkları mastektomi vakalarında postoperatif ağrı skorlarında ve morfin tüketiminde azalma, laringoskopiye bağlı daha az hemodinamik yanıt olduğu belirtilmiştir. Mastektomilerde postoperatif ağrı kontrolünde NSAIII'ler sık tercih edilen ajanlardır. Çalışmamızda NSAIII ilaç olan tenoksikamın mastektomilerde preemptif kullanımının postoperatif ağrı skorlarında belirgin farklılık oluş- 
turmadığı ancak ilk analjezik gereksinim zamanın uzattığı, postoperatif analjezik ihtiyacını azalttığı görülmüştür. Çalışmamızda intraoperatif dönemde hemodinamik parametreler açısından gruplar arası fark bulunmamıştır. Preemptif ilaç uygulanan grupta indüksiyon ve laringoskopi sonrasında hemodinamik yanıt diğer gruplardaki hastalarla benzer bulundu. Çalışmamızda intraoperatif dönemde tüm hastalara standart anestezi protokolü uygulanmış olup benzer dozlarda fentanil kullanıldı. Çalışmamızda hemodinamik parametrelerde gruplar arasında fark bulunmamasında tüm hastalarda benzer anestezik derinliğinin varlığının etkisi olduğu düşünüldü.

Postoperatif ağrı yönetiminde preemptif analjezi yönetiminin klinik etkinliği ile ilgili fikir birliği bulunmamaktadır. Akça ve ark. ${ }^{19}$ inguinal herni onarımı ve laparoskopik kolesistektomi uygulanan hastalarda preoperatif tenoksikam $20 \mathrm{mg}$ uygulamasını plasebo grubuyla karşılaştırmış, preoperatif tenoksikam uygulamasının etkin postoperatif ağrı kontrolü sağladığını göstermişlerdir. Yazkan ve ark'nın ${ }^{20}$ tonsillektomi geçiren hastalarda yaptıkları çalışmada tenoksikamın yetişkin hasta grubunda güvenle kullanılabilecek bir ajan olduğu, preemptif uygulamada tenoksikamın postoperatif analjezi ihtiyacını anlamlı düzeyde azalttığ1 ve postoperatif dönemde hasta konforunu arttırdı $\breve{1}$ sonucuna varmışlardır. Danou ve ark. ${ }^{21}$ ise total abdominal histerektomi vakalarında yaptıkları çalışmada preoperatif dönemde $20 \mathrm{mg}$ ve $40 \mathrm{mg}$ tenoksikam iv uygulamasının postoperatif ağrı tedavisinde etkin olmadığını bildirmişlerdir. Yapılan bir metaanalizde preemptif uygulanan epidural analjezi, lokal anestezik ajan infiltrasyonu ve NSAIII kullanımının postoperatif ilk analjezik gereksinim zamanını uzattığ 1 , analjezik tüketimini azalttığ1 ancak postoperatif ağr1 skorlarını etkilemediği belirtilmiştir ${ }^{22}$. Çalışmamızda da preemptif tenoksikam uygulamasının postoperatif dönemde ilk analjezik gereksinim süresini uzattığ 1 ve ek analjezik ihtiyacını azalttığ 1 görüldü. Derlenme ünitesinde değerlendirilen postoperatif sıfırıncı saat VAS skorları tenoksikam uygulanan gruplarda benzer bulunurken, plasebo uygulanan grubun VAS skorlarından düşük saptand1. Diğer zamanlarda hastaların VAS skorları tüm gruplarda benzer bulundu. Yağar ve ark'nın ${ }^{23}$ laparoskopik kolesistektomilerde yaptığı çalışmada tenoksikamın preemptif ve postoperatif iv $40 \mathrm{mg}$ tenoksikam uygulaması karşılaştırılmış, çalışmamıza benzer şekilde preemptif tenoksikam uygulamasının postoperatif uygulamaya göre ağrı algısını değiştirmediği, hastalarda benzer VAS skorları olduğu vurgulanmıştır.

Uygulanan cerrahi işlem ve süresi, doku hasarının tipi ve genişliği, preemptif uygulamanın zamanı ve metodu, kullanılan ajanların türü ve intraoperatif kullanılan diğer maddelerle etkileşim gibi durumlar preemptif analjezinin etkinliği ile ilişkili olabilecek faktörlerdendir $^{24}$. Bu faktörlerin birçoğunun klinik çalışmalar- da kontrol edilmesi zordur ve bu durum preemptif analjezi uygulanan çalışmalarda görüş farklılıklarına sebep olabilirr ${ }^{25}$. Bizim çalışmamızda, preemptif analjeziyi etkilediği bilinen ve kontrol edebileceğimiz birçok faktör (cerrahi tipi, preemptif analjezi uygulama zamanı ve metodu, kullanılan ajanların türü, hastaların demografik özellikleri, ASA sinıflaması vb.) standardize edilmeye çalışıldı. Preemptif NSAIİ uygulamasının analjezik etkinliği konusunda literatürde birçok çalışma bulunmaktadır. Yeterli analjezik etki gösteremeyen preemptif NSAIİ çalışmalarında bu sonuç perioperatif yetersiz nosiseptif afferent blokaj1na ya da kullanılan analjezik ajanın farmakolojik etkisi geçtikten sonra merkezi duyarlılığın gelişmesine atfedilebilir. Bu nedenlerden dolayı, etki süresi postoperatif döneme kadar uzanan analjeziklerin kullanılması önerilmektedir ${ }^{26,27}$. Çalışmamızda ortalama eliminasyon yarı ömrü uzun (ortalama 67 saat), \%100 lük biyoyararlılığ1, yaklaşık \%99'luk kan proteinlerine bağlanma oranı olan tenoksikam preemptif ajan olarak tercih edilmiştir. Çalışmamızda kullanılan tenoksikamın dozu da daha önce yapılan benzer çalışmalar 1şı̆̆ında, analjezik etkinlikler ve yan etkiler göz önüne alınarak $20 \mathrm{mg}$ olarak belirlendi. NSAIII'lerin analjezik etki mekanizmasında kullanılan araşidonik asit yolağının baskılanması için belli bir süreye gerek vardır bu sebeple analjezik etki iv uygulamanın ardından hemen gelişmez ${ }^{6,8,9}$. Yapılan birçok preemptif analjezi çalışmalarında çalışma ilacı hastalara cerrahi başlangıcından ortalama 15-30 dk önce uygulanmıştır. O’Hanlon ve ark. ${ }^{28}$ ve Colbert ve ark. ${ }^{29}$ yaptıkları çalışmalarda meme biyosisinden $30 \mathrm{dk}$ önce tenoksikam uygulamışlar ve postoperatif etkin bir analjezi sağladığını göstermişlerdir. Shalaby ve ark. ${ }^{30}$ yaptığ 1 çalışmada aktif vaginal doğum fazında iv $20 \mathrm{mg}$ tenoksikam uygulamış, belirgin maternal ve neonatal yan etki görülmeksizin hastalarda doğum sonrası uterin kasılma ağrısının olmadığı ve analjezik etkinliğin yüksek olduğunu belirtmişlerdir. Çalışmamızda da preemptif grupta hastalarımıza cerrahi işlem başlang1cından 30 dakika önce tenoksikam $20 \mathrm{mg}$ iv tek doz olarak uyguland.

Hastalar preoperatif dönemde VAS skoru konusunda bilgilendirilmelerine rağmen postoperatif dönemde ağrı şiddeti konusunda net derecelendirme yapamayabilirler. Postoperatif dönemde hastaların HKA ile opioid tüketimlerinin takibi ağrı düzeyini değerlendiren daha objektif bir yöntemdir ve birçok postoperatif ağrı çalışmasında bu yöntem kullanılmaktadır. Bizim çalışmamızda postoperatif sıfırıncı saat VAS skorları preemptif tenoksikam grubu ile cerrahi bitiminde tenoksikam uygulanan grup benzer, plasebo grubundan düşük görülmüş; diğer zamanlarda hastaların VAS skorlarında gruplar arası fark bulunmamıştır. Hastaların ağrı algılarında belirgin farklılık yok şeklinde görülse de preemptif tenoksikam uygulanan gruptaki HKA ile morfin tüketiminin diğer iki gruba göre daha 


\section{Preemptif ve Postoperatif Tenoksikam Kullanımı}

düşük olması bu uygulamanın analjezi açısından daha avantajlı olduğunu göstermektedir.

Postoperatif bulantı-kusma genel anestezi uygulamalarının erken döneminde sıklıkla karşılaşılan bir durumdur, opioid kullanımında ise görülme sıklığı artmakta$\mathrm{d}_{1} \mathrm{r}^{20,22}$. Arslan ve ark. ${ }^{31}$ tiroid ameliyatlarinda cerrahi bitiminde kullanılan iv parasetamol ve lornoksikamın hastalarda postoperatif opioid ihtiyacinı ve bulant1kusma oranını azalttığını belirtmiştir. Özkan ve ark'larının $^{32}$ preemptif tramadol ve deksketoprofen uyguladıkları laparoskopik kolesistektomi çalışmasında bulantı-kusmanın en yoğun olarak, anestezik etkinin ortadan kalkıp ağrının hissedildiği ve buna bağlı opioid tüketiminin fazla olduğu ilk 4 saatte gözlendiği belirtilmiştir. Çalışmamızda her 3 grupta bulantıkusma en yoğun postoperatif ilk 2 saat içinde gözlenmiştir ancak preemptif tenoksikam uygulamasında ilk 2 saat içinde bulantı kusma sıklığı diğer hastalara göre düşük bulunmuştur. İlk saatlerde görülen bulant1kusma genel anestezi komplikasyonu olarak değerlendirmekle birlikte kontrol grubunda postoperatif 4 . saat ve sonrasında daha yoğun bulantı-kusma görülmesinin bu gruptaki hastalarda morfin tüketiminin daha fazla olmasıyla ilişkili olabileceği kanısındayız.

Postoperatif dönemde hasta memnuniyetinin derecesi özellikle hastaların ağrı şiddetiyle değişim göstermektedir. Jamison ve ark'nın ${ }^{33}$ büyük ortopedik operasyon geçiren hastalarda yaptıkları postoperatif hasta memnuniyeti çalışmasında, postoperatif ağrı kontrolü sağlanan hastalarda hasta memnuniyeti tama yakın bulunmuştur. Bizim çalışmamızda da postoperatif VAS skorları yüksek ve postoperatif analjezi için morfin tüketiminin fazla olduğu kontrol grubunda hasta memnuniyeti düşük bulunurken tenoksikam uygulanan gruplarda hasta memnuniyeti düzeyi yüksek bulundu. Postoperatif dönemde hastaların klinik bakımı ile ilgilenen ve takiplerinden sorumlu klinik hemşirelerinin memnuniyet düzeyi ise gruplar arasında benzer bulundu. Hemşire memnuniyetinin her grupta benzer oluşu uygulanan HKA yöntemi ile tüm hastaların kendi analjezik ihtiyaçlarını karşılayabilmesi ile açıklanabilir.

Çalışmamızda anestezi derinliğinin ölçülmesinde bir monitorizasyon kullanılmamış olup tüm hastalara uygulanan standart anestezi protokolü ile benzer anestezi derinliğinin olduğu varsayılmıştır.

Preemptif tenoksikam uygulamasının hastalarda ilk analjezik gereksinim zamanını uzatması ve postoperatif morfin tüketimini azaltması sebebiyle mastektomi uygulanan hastalarda postoperatif ağrı kontrolünde etkin olduğu kanısındayız.

Çalıșmamızı finansal olarak destekleyen kiși veya kuruluş yoktur ve yazarların herhangi bir çıkar dayalı ilişkisi bulunmamaktadır.
Etik Kurul Onay Bilgisi:

Onaylayan Kurul: Uludağ Üniversitesi Tıp Fakültesi Klinik

Araştırmalar Etik Kurulu

Onay Tarihi: 26.05.2009 tarihli ve

Karar No: 2009-9/60

Araștırmacı Katkı Beyanı: Fikir ve tasarım: A.N.B., F.N.K; Veri toplama ve işleme: A.N.B., F.A; Analiz ve verilerin yorumlanması: A.N.B., Ü.K, Makalenin önemli bölümlerinin yazılması: A.N.B.

Finansal Destek Beyanı: Çalışmaya finansal destek veren kurum ya da kuruluş bulunmamaktadır.

Çıkar Çatıșması Beyanı: Makale yazarlarının çıkar çatıșması yoktur.

\section{Kaynaklar}

1. Karamanoğlu A, Özer FG. Mastektomili hastalarda evde bakım. Meme Sağlığı Dergisi 2008;4:3-8.

2. Björkman B, Arner S, Hyden LC. Phantom breast and other syndromes after mastectomy: eight breast cancer patients describe their experiences over time: a 2-year follow-up study. J Pain. 2008;9(11):1018-25.

3. Dahl JB, Kehlet $\mathrm{H}$. The value of pre-emptive analgesia in the treatment of postoperative pain. Br J Anaesth 1993;70:434-9.

4. Hebl JR, Dilger JA, Byer DE, et al. A pre-emptive multimodal pathway featuring peripheral nerve block improves perioperative outcomes after major orthopedic surgery. Reg Anesth Pain Med 2008;33:510-7.

5. Wall PD. The prevention of postoperative pain. Pain; 1988;33:289-90.

6. Grape S, Tramer MR. Do we need preemptive analgesia for the treatment of postoperative pain. Best Pract Res Clin Anaesthesiol 2007; 21:51-63.

7. Katz J, McCartney CJ. Current status of pre-emptive analgesia. Curr Opin Anesthesiol 2004;15:435-41.

8. Moote C. Efficacy of non steroidal antiinflamatory drugs in the management of postoperative pain. Drugs 1992;44(5):14-29.

9. Nilsen OG. Clinical pharmocokineties of tenoksikam. Clin Pharmacokinet 1994;26:16-43.

10. Merry FA, Webstar SC, Holland RL, et al. Clinical tolerability of perioperative tenoxicam in 1001 patients-a prospective, controlled, double-blind, multi-centre study. Pain 2004;111: 313-22.

11. Morgan GE, Mikhail MS. Ağrı tedavisi. In: Lüleci N, eds. Klinik Anesteziyoloji. 4. Bask1. İstanbul: Nobel Kitabevi; 2008:359-412.

12. Merry AF, Sidebotham DA, Middleton NG, Calder MV, Webster CS. Tenoxicam $20 \mathrm{mg}$ or $40 \mathrm{mg}$ after thoracotomy: a prospective, randomized, double-blind, placebo-controlled study. Anaesth Intensive Care 2002;30:160-6.

13. Talbot H, Hutchinson SP, Edbrooke DL, Wrench I, Kohlhardt SR. Evaluation of a local anaesthesia regimen following mastectomy. Anaesthesia 2004;59:664-7.

14. Huang TT, Parks DH, Lewis SR. Outpatient breast surgery under intercostal block anesthesia. Plast Reconstr Surg 1979;63:299-303.

15. Lynch EP, Welch KJ, Carabuena JM, Eberlein TJ. Thoracic epidural anesthesia improves outcome after breast surgery. Ann Surg 1995;222:663-9.

16. Coveney E, Weltz CR, Greengrass R, Iglehart JD, Leight GS, Steele SM, et al. Use of paravertebral block anesthesia in the surgical management of breast cancer: Experience in 156 cases. Ann Surg 1998;227:496-501. 


\section{A.N. Balkaya, ark.}

17. Prashanth Gowtham Raj SK, Bhagyashree A. Efficacy of Preemptive oral pregabalin for prolonging post-operative analgesia in modified radical mastectomies. Indian Journal of Clinical Anaesthesia 2016;3(3): 374-9

18. Bharti N, Bala I, Narayan V, et al. Effect of gabapentin pretreatment on propofol consumption, hemodynamic variables, and postoperative pain relief in breast cancer surgery. Acta Anaesthesiol Taiwan 2013;51:10-13.

19. Akca T, Colak T, Kanik A, Yaylak F, Caglikulekci M, Aydın S. The effect of preoperative intravenous use of tenoxicam: a prospective, double-blind, placebo-controlled study. J Invest Surg 2004; 17:333-8.

20. Yazkan FO, Unsal EE. Tenoxicam Pain Effect after Tonsillectomy. SDU Journal of Health Science Institute 2017;8(1):12430.

21. Danou F, Paraskeva A, Vassilakopoulos T, Fassoulaki A. The analgesic efficacy of intravenous tenoxicam as an adjunct to patient-controlled analgesia in total abdominal hysterectomy. Anesth Analg 2000;90:672-6.

22. Ong CK, Lirk P, Seymour RA, Jenkins BJ. The efficacy of preemptive analgesia for acute postoperative pain management: A meta-analysis, Anesth Analg 2005;100:757-73.

23. Yagar S, Turan SK, Ay1k I, et al. Comparative study of preemptive and postoperative iv tenoxiam in laparoscopic cholecystectomy. Türk Anest Rean Der Dergisi 2011;39:19-24.

24. Moiniche S, Kehlet H, Dahl JB. A qualitative and quantitative systematic review of preemptive analgesia for postoperative pain relief: the role of timing of analgesia. Anesthesiology 2002;96:725-41.

25. Klein SM, Greengraas RA, Steele SM, et al. A comparison of $0.5 \%$ bupivacaine, $0.5 \%$ ropivacaine, and $0.75 \%$ ropivacaine for interscalene brachial plexus block. Anesth Analg 1998;87:1316-9.

26. De Decker K, Vercauteren M, Hoffmann V, Lasters B, Adriaensen $\mathrm{H}$. Piroxicam versus tenoxicam in spine surgery: a placebo controlled study. Acta Anaesthesiol Belg 2001; 52: 265-69.

27. Vandermeulen EP, Van Aken H, Scholtes JL, Singelyn F, Buelens A, Haazen L. 1Intravenous administration of tenoxicam $40 \mathrm{mg}$ for post-operative analgesia: a double-blind, placebo-controlled multicentre study. Eur J Anaesthesiol 1997; 14: 250-57.

28. O’Hanlon DM, Thambipillai T, Colbert ST, Keane PW, Given HF. Timing of pre-emptive tenoxicam is important for postoperative analgesia. Can J Anaesth 2001;48:162-6.

29. Colbert ST, O’Hanlon DM, McDonnell C, Given HF, Keane PW. Analgesia in day case breast biopsy- the value of preemptive tenoxicam. Can J Anaesth 1998;45: 217-22.

30. Shalaby HS, Hemada HM, Faris MA. Efficacy of Intravenous Tenoxicam as an Analgesic during the First Stage of Labor: A Randomized Controlled Trial. The Egyptian Journal of Hospital Medicine 2018;70(4): 601-9.

31. Arslan M, Çiçek R, Celep B, Yılmaz H, ÜSTÜN KH . Tiroidektomi sonrası postoperatif ağrıda intravenöz parasetamol ve lornoksikamın analjezik etkilerinin karşılaştırılması. A ğr1 2011;23:160-66.

32. Ozkan S, Yavaşcaoğlu B, Kaya FN, et al. Comparing efficacy of preemptively used dexketoprofen and tramadol for postoperative pain in patients underwent laparoscopic cholecystectomy. JCEI 2015; 6 (1): 44-51

33. Jamison RN, Ross MJ, Hoopman P, et al. Assessment of postoperative pain management: patient satisfaction and perceived helpfulness. Clin J Pain 1997;13:229-36. 